\title{
KEHIDUPAN SOSIAL EKONOMI JURU PELIHARA SITUS CAGAR BUDAYA DI MADIUN TAHUN 2013
}

\section{Hermawan Purwo Sasmito \& Muhammad Hanif*}

\begin{abstract}
Abstrak
Penelitian ini dilakukan dengan tujuan untuk mengetahui kehidupan sosial ekonomi yang dialami juru pelihara situs cagar budaya tahun 2013. Selain itu sejarah keberadaan juru pelihara di madiun. Juru pelihara kebanyakan berasal dari juru kunci benda cagar budaya setempat. Adapun juru pelihara terbagi menjadi juru pelihara BPCB Trowulan, Provinsi dan juru pelihara sukarela. Pada tahun 2013 kehidupan sosial juru pelihara sudah mengalami peningkatan namun juga ada sebagian dari juru pelihara masih memerlukan perhatian. Perkembangan yang terjadi saat ini juru pelihara telah mampu meningkatkan kehidupan ekonomi mereka melalui pekerjaan mandiri. Disamping itu ada juga juru pelihara yang sudah mampu mengembangkan potensi wilayahnya. Ini merupakan salah satu wujud dari kehidupan sosial yang dapat meningkatkan tperekonomian masyarakat sekitar. Selain itu contoh lain yaitu dengan diadakannya kegiatan tradisi upacara adat di sekitar benda cagar budaya yang dibantu pemerintah daerah telah mampu memberikan pengaruh dalam sendi ekonomi. Untuk pihak pemerintah khususnya pemerintah daerah setempat memang belum memberikan anggaran khusus terhadap benda cagar budaya dan juru pelihara. Namun tetap memberikan perlindungan dan pengawasan terhadap keberadaan mereka. Selain itu juga tetap memberikan bingkisan sebagai rasa terima kasih kepada juru pelihara. Kemudian dari pihak BPCB Trowulan dan pemerintah provinsi telah memberikan perhatian yang banyak kepada keberadaan juru pelihara sebagai bagian dari satuan kerja dalam bidang kebudayaan. Ini dibuktikan dengan di berikannya tunjangan secara berkala dan penyediaan kebutuhan untuk pemeliharaan benda cagar budaya.
\end{abstract}

\section{Kata kunci: Juru Pelihara, Situs Cagar Budaya, Sosial Ekonomi}

\section{Pendahuluan}

Sebuah wilayah muncul bukan secara langsung tetapi melalui sebuah proses. Proses menjadi bagian dari sebuah sejarah yang terus diingat dan digunakan sebagai identitas bangsa. Sejarah adalah sebuah kronik, atau memiliki setiap peristiwa dalam periode waktu. Namun tidak semua peristiwa menjadi bagian dari sejarah. Sebuah peristiwa yang menjadi sejarah adalah peristiwa yang memiliki keunikan dan meninggalkan sebuah jejak-jejak sejarah.
Dengan adanya jejak sejarah menjadi bukti adanya peristiwa penting yang terjadi. Jejak sejarah yang muncul mampu menjelaskan peristiwa dan menjadi sumber bukti kekuatan dari peristiwa.

Sebagai wujud jejak sejarah adanya peninggalan kebudayaan manusia. Banyak yang menjadi hasil dari kebudayaan, dan salah satunya yaitu seni bangunan. Indonesia adalah salah satu Negara yang memiliki banyak hasil kebudayaan berupa seni bangunan contohnya ialah benteng, keraton, 
tempat ibadah, candi dan yang paling kuno berwujud punden berundak. Namun kebudayaan yang banyak terdapat di Indonesia adalah candi. Candi banyak menjadi bukti sejarah peninggalan dalam bidang agama karena sebagai tempat pemujaan kepada para dewa. Candi merupakan istilah yang digunakan untuk menyebut semua bangunan peninggalan di Indonesia yang dipengaruhi oleh arsitektur hindu atau budha (Ririn Darini, 2013: 58). Candi atau komplek percandian merupakan bagian penting dalam perjalanan sebuah perkembangan wilayah. Karena candi akan menjelaskan tentang asal usul wilayah, terjadinya sebuah peristiwa dan juga waktu yang menunjukkan peristiwa itu terjadi.

Keberadaan sebuah candi akan mampu memberikan penjelasan tentang sebuah gejala sosial yang terjadi di suatu wilayah sepanjang kurun waktu tertentu. Sehingga mampu memberikan penjelasan penelitian dan kronologi sebuah peristiwa.Sejarah bangunan candi suatu wilayah mampu memberikan sebuah pengaruh secara nyata dalam segi kehidupan, khususnya segi pamor atau nama besar wilayah. Misalkan saja Magelang dengan Borobudur, Malang dengan candi Singosari atau juga Dataran Dieng dengan bangunan kelompok candi Dieng. Dalam fungsi yang lain candi juga menjadi sebagai bentuk kekuasaan politis. Dengan adanya keberadaan candi dan ukuran candi akan memberikan legitimasi dan kemegahan dari sebuah kerajaan. Tentunya ini akan memberikan sebuah nama besar terhadap wilayah yang dikuasai dan juga wilayah pembangunan.

Oleh karena itu penting adanya melestarikan peninggalan sejarah yang terdapat di wilayahnya. Dengan melestarikan peninggalan sejarah seperti candi dan situs sejarah lain memberikan pengetahuan pendidikan dan juga kesadaran sejarah. Selain itu dengan menjaga kelestarian benda peninggalan sejarah mampu memberikan inspirasi untuk membangkitkan rasa nasionalisme terhadap tanah air. Tempat peninggalan sejarah ini juga mampu menjadi sebuah objek wisata. Dengan ini mampu membangkitkan ekonomi wilayahnya. Dengan begitu perawatan terhadap benda peninggalan sejarah menjadi baik.

Namun pada masa sekarang ini keberadaan benda cagar budaya seperti candi mengalami penurunan. Banyaknya kasus hilangnya candi dan kerusakan candi akan menghilangkan bukti budaya. Sehingga identitas asli setempat akan hilang seiring dengan melemahnya dan menghilangnya candi. Untuk itu keberadaan candi memerlukan sebuah penanganan dan pemeliharaan yang serius. Pemeliharaan dan pengelolaan yang baik akan memberikan citra yang 
baik terhadap perkembangan di wilayahnya. Yang pertama kali tentunya sebuah wilayah memiliki aturan-aturan yang mengatur dan melindungi sebuah situs kesejarahan seperti candi. Situssitus berupa candi ini dimasukan kedalam benda cagar budaya yang terlindungi di wilayahnya.

Situs cagar budaya yaitu lokasi yang berada didarat dan/atau di air yang mengandung Benda Cagar Budaya, Bangunan Cagar Budaya, dan/atau Struktur Cagar Budaya sebagai hasil kegiatan manusia atau bukti kejadian pada masa lalu (UU Cagar Budaya No. 11 tahun 2010). Selain itu dalam pelestarian dan pengelolaan benda cagar budaya candi ada seseorang yang bertanggung Jawab. Seseorang yang dipercaya untuk memelihara, melestarikan dan mengelola sebuah benda cagar budaya disebut Juru Pelihara. Peran juru pelihara situs cagar budaya merupakan kunci utama dalam keberadaan sebuah Sehingga menghindarkan benda cagar budaya dari kerusakan.

Umumnya seorang juru pelihara bertugas menjaga, memelihara dan merawat benda cagar budaya fisik seperti candi dan benda budaya bangunan. Dalam pemeliharan dan pengelolaan benda cagar budaya terdapat beberapa unsur yang bertanggung Jawab yaitu Negara,
Pemerintah Daerah, Tim Ahli Cagar Budaya dan Juru Pelihara setempat. Semua unsur dalam pelestarian cagar budaya ini saling berkerjasama dalam pemeliharaan sebuah situs cagar budaya. Dalam lingkup yang lebih kecil yaitu di sebuah kawasan daerah lingkup kota atau kabupaten unsur yang bertanggung Jawab dalam pemeliharaan yaitu pemerintah kota atau kabupaten yang bekerjasama dengan juru pelihara. Juru pelihara tersebar sesuai dengan persebaran wilayah situs cagar budaya. Tentunya wilayah ini memiliki aturan yang ditetapkan untuk menjadi sebuah kawasan cagar budaya. Sekarang ini banyak yang belum memahami tentang juru pelihara dari pemeliharan situs cagar budaya. Banyak yang menganggap bahwa juru pelihara memiliki banyak kesamaan dengan sebutan juru kunci atau juga seorang abdi dalem.

Saat ini masyarakat di sekitar tempat cagar budaya belum mengetahui tentang juru pelihara dan kehidupannya. Kebanyakan masyarakat hanya mengenal tentang nama juru kunci, kuncen dan abdi dalem.. Keberadaan juru pelihara telah tenggelam oleh nama sebuah benda cagar budaya yang dipelihara. Sebenarnya sebuah benda cagar budaya tidak akan lepas dari sebuah peran seorang juru pelihara. Sedikit yang menjelaskan tentang kehidupan dari seorang juru pelihara. selain itu 
masyarakat umum juga belum memahami tentang latar belakang seseorang menjadi juru pelihara.

Kondisi Madiun yang
merupakan wilayah strategis dengan aliran sungai dan pegunungan membuat Madiun menjadi salah satu wilayah yang banyak memiliki benda cagar budaya. Ini muncul karena sebuah situs percandian umumnya terletak di pinggir aliran sungai dan gunung. Karena gunung dipercaya sebagai tempat para dewa pada masa kerajaan Indonesia. Secara umum tidak banyak yang mampu menguraikan juru pelihara dalam pembelajaran lokal. Tentunya pembelajaran lokal merupakan pembelajaran yang mampu membangkitkan rasa cinta dalam kebudayaan lokal

Setiap wilayah memiliki benda cagar budaya yang tentunya dijaga oleh seorang juru pelihara. Saiful Huda Seorang Juru Pelihara Situs Cagar Budaya Ngurawan Madiun (wawancara, 20 Februari 2014) berpendapat bahwa masih ada beberapa situs cagar budaya yang belum memiliki seorang juru pelihara. hal ini terjadi karena belum adanya kesadaran masyarakat terhadap pelestarian benda cagar budaya di wilayahnya. Kesadaran akan benda budaya mampu membangkitkan potensi dalam berbagai bidang kehidupan.
Dalam perkembangannya seorang juru pelihara memiliki banyak pengalaman yang menjadi peristiwa unik dan mendidik tentang upaya menjadi seorang pemelihara situs cagar budaya dalam sosial masyarakat. Sehingga diharapkan masyarakat luas menghargai dan mengetahui nilai dari sebuah profesi. Salah satu masalah yang akan muncul yaitu adanya perbedaan ekonomi sesama juru pelihara. Kemudian latar belakang yang menimbulkan sebuah perbedaan perekonomian diantara juru pelihara dan status juru pelihara. Sehingga perlu adanya penelitian yang mendalam tentang kehidupan juru pelihara.

Dari latar belakang masalah dan batasan masalah tersebut diatas, maka dapatdirumuskan masalah dalam penelitian ini yaitu : Bagaimanakah kehidupan sosial ekonomi juru pelihara situs cagar budaya di Madiun tahun 2000-2013?

\section{Tinjauan Pustaka}

\section{A. Kehidupan Sosial Ekonomi}

Sosial secara etimologis berasal dari bahasa latin yaitu sofie yang berarti bercocok tanam. Kemudianberkembang menjadi socius yang memiliki arti teman, kawan, berkembang dan mengalami perubahan menjadi sosial artinya berteman, bersama dan berserikat. Ilmu sosial pada dasarnya merupakan ilmu yang mempelajari perilaku dan aktivitas manusia 
dalam kehidupan bersama. Dengan demikian ilmu sosial mempelajari bagaimana hubungan manusia dengan manusia, dan bagaimana hubungan manusia dengan lingkungannya (Supardi, 2011:21).

Namun pendapat berbeda di kemukakan oleh Supardan (2008: 25) bahwa sosial merujuk pada sebuah arti masyarakat. Manusia membutuhkan satu sama lain untuk bertahan hidup sebagai manusia dan ketergantungan ini menghasilkan kerjasama yang bersifat ajeg dalam membentuk masyarakat tertentu. Dengan demikian manusia merupakan makhluk sosial.

Dari pendapat para ahli dapat disimpulkan bahwa sosial merupakan perilaku dan aktivitas individu dalam kelompok masyarakat. Sedangkan ilmu yang mempelajari tentang berbagai perilaku dan aktivitas manusia dalam kehidupan bersama dalam masyarakat adalah ilmu sosial. Aktivitas dan perilaku sosial ini berhubungan langsung antara sesama manusia juga lingkungannya

dalam masyarakat sosial yang saling berhubungan secara berkelanjutan akan menimbulkan sebuah kehidupan sosial. Kehidupan sosial juga merupakan proses sosial. Proses sosial adalah cara-cara berhubungan yang dilihat apabila orang perorangan dan kelompok-kelompok sosial saling bertemu dan menentukan system serta bentuk hubungan tersebut atau apa yang terjadi apabila ada perubahan yang mempengaruhi pola kehidupan yang ada (Soekanto, 1990:66).

Adanya cara-cara berhubungan dalam proses sosial menjadi bagian penting dalam kehidupan sosial. Kelompok sosial secara tidak sadar akan saling menjalin hubungan sesama individu ataupun juga dengan kelompok. Hubungan dan komunikasi sosial ini yang merupakan wujud dari interaksi sosial. Interaksi sosial merupakan hubungan sosial yang dinamis yang menyangkut hubungan antara perorangan dan kelompok sosial (Soekanto, 1990:67).

Melalui komunikasi antara individu dan masyarakat ini memunculkan sikap untuk saling membutuhkan antara sesama. Kegiatan ini merupakan bagian dari kehidupan sosial. Sehingga dapat disimpulkan bahwa Kehidupan sosial merupakan aktivitas dan perilaku manusia atau individu dalam menjalin sebuah hubungan dengan individu lain maupun dengan kelompok dalam satuan masyarakat.

Tidak dapat dihindarkan bahwa aktivitas manusia dalam masyarakat akan mempengaruhi berbagai aspek kehidupannya. Dalam hal ini kehidupan ekonomi individu. Karena setiap individu hidup dalam masyarakat untuk memnuhi kehidupan ekonomi dalam mempertahankan eksistensinya. Ekonomi berasal dari bahasa yunani, yaitu Oikos Nomos atau Oikonomia. Secara bahasa, Oikos Nomos atau Oikonomia sulit untuk di terjemahkan. Namun bangsa barat 
menerjemahkannya dengan Management of Bousebold Or Estate yaitu tata laksana rumah tangga atau kepemilikan (Sastradipoera dalam Supardi, 2011:110). Adapun ekonomi sebagai pengelolaan dalam rumah tangga adalah usaha dalam pembuatan keputusan dan pelaksanaannya yang berhubungan dengan pengalokasian sumber daya rumah tangga yang terbatas diantara anggotanya, dengan mempertimbangkan kemampuan, usaha dan keinginan masing-masing (Damsar, 2009:9-10).

Artinya ekonomi merupakan penataan dan pengelolaan segala sesuatu yang dimiliki oleh sesorang individu atau kelompok tanpa campur tangan dari orang lain. Pengelolaan ekonomi diselaraskan dengan kemampuan dasar seorang individu. Misalkan kemampuan dan usaha yang dilakukan dalam mengelola sebuah system dalam ekonomi.

Ilmu ekonomi memiliki keterkaitan dengan ilmu sosial. Ilmu sosial dan ilmu ekonomi memiliki kesamaan dalam obyek formalnya yaitu manusia dan perilakunya (Supardi, 2011:128). Hal ini berarti manusia menjadi titik pusat dalam semua penelitian dan kajian ilmu sosial dan ekonomi. Secara nyata perilaku sosial masyarakat merupakan bagian dari sosiologi. Semua perilaku sosial yang melibatkan kehidupan sosial menjadi obyek kajian sosiologi.

Aktivitas ekonomi merupakan upaya untuk memenuhi kebutuhan hidup dalam usaha melestarikan keberadaannya. Usaha ini tentunya melibatkan kehidupan sisoal dalam pemenuhannya. Hal ini merupakan bagian dari sosiologi ekonomi dalam masyarakat. Sosiologi ekonomi mempelajari berbagai macam kegiatan yang sifatnya kompleks dan melibatkan produksi, distribusi, pertukaran dan konsumen barang dan jasa yang bersifat langka dalam masyarakat (Dany Haryanto, 2011:73).

Sosial ekonomi menurut Soekanto (dalam Resty Nikiuluw, 20011:15) merupakan posisi seseorang dalam masyarakat berkaitan dengan orang lain dalam arti lingkungan pergaulan, prestasinya, dan hak - hak serta kewajibannya dalam hubungannya dengan sumber daya. Dari pendapat diatas dapat disimpulkan bahwa sosial ekonomi merupakan usaha manusia untuk memenuhi kebutuhan dalam mencapai kemakmuran dan posisi sosial dalam masyarakat. Sehingga memiliki kedudukan atau status sosial dalam sebuah system masyarakat.

Pola kehidupan sosial mengharuskan aktivitas antara individu yang saling berhubungan dan berkomunikasi dalam pemenuhan kebutuhan membuat munculnya sebuah proses sosial. Dengan proses sosial interaksi antara individu dan kelompok yang mengadakan system perhubungan mengenai cara hidup yang telah ada memunculkan aksi dan reaksi secara timbal balik untuk memecahkan 
masalah (Abu Ahmadi, 1991:99-100). Interaksi sosial yang terjalin antara individu maupun kelompok sosial ini akan menimbulkan berbagai pengaruh dalam pembentukan setiap individu. Sebuah pola gerak dan sikap individu terbentuk melalui sebuah proses dalam interaksi sosial.

Namun pendapat yang berbeda diungkapkan oleh Horowitz dan O'brien (1985:352) bahwa komposisi sosial ekonomi status atau SES yaitu termasuk pendidikan, penghasilan, pekerjaan, perumahan buku dan alat-alat rumah tangga. Ini berarti setiap pendidikan dan pekerjaan yang dimiliki seorang individu akan mempengaruhi besarnya penghasilan dan pemenuhan kebutuhan hidup seseorang. Tentunya tingkat pendidikan dan jenis pekerjaan seseorang akan mampu memberikan status sosial.

\section{B. Juru Pelihara}

Dalam system kerajaan terdapat sebuah stuktur jabatan. Struktur jabatan ini membentuk sebuah kelas-kelas sosial yang terjadi dalam lingkup kerajaan. Status ssosial ini akan mempengaruhi kehidupan para raja dan rakyat. Menurut Moedjianto (1997:113-116) Terdapat lima tingkatan jabatan untuk mengurusi pemerintahan dalam kerajaan di Jawa antara lain : Pejabatpejabat tinggi dalam kraton dan daerah kutagara, Pejabat-pejabat di wilayah agung, Pejabat-pejabat di wilayah mancanegara, Pejabat-pejabat di daerah pasisiran dan Jabatan-jabatan lebih rendah. Para abdi dalem ini ditempatkan sesuai dengan bidang keahliannya. Pada masa saat ini orang yang memiliki keahlian sering dissebut dengan Juru. Misalkan orang yang bertugas mengelola tempat suci atau keramat disebut juru kunci.

Adapun tentang Juru pelihara merupakan seseorang yang bertugas untuk menjaga, melestarikan dan merawat situs atau benda cagar budaya. Menurut Pasal 62 UU No. 11 Tahun 2010 Tentang Cagar Budaya bahwa Pengamanan Cagar Budaya untuk menjaga dan mencegah Cagar Budaya agar tidak hilang, rusak, hancur, atau musnah.dapat dilakukan oleh juru pelihara dan/atau polisi khusus. Yang merupakan seorang juru pelihara dipilih berdasarkan letak wilayah dengan benda cagar budaya dan mengetahui serta memahami tentang benda cagar budaya yang dilestarikan.

Dalam pelaksanaan tugasnya, juru pelihara bekerjasama dengan pemerintah dan tim ahli cagar budaya. Dalam Keputusan Gubernur No. 50 tahun 2013 tentang Tim Ahli Cagar Budaya Jawa Timur telah diputuskan bahwa tim ahli cagar budaya berhak membentuk pembantu pelaksana sesuai dengan kebutuhan. Tentunya juru pelihara juga bertanggung Jawab kepada tim ahli cagar budaya selain kepada balai pelestarian cagar budaya dan pemerintah. Selain itu berdasarkan peraturan yang sama, KEPGUB No. 5 tahun 2013 bahwa tim ahli cagar budaya melaporkan setiap kondisi benda cagar kepada gubernur. 
Untuk laporan kondisi benda cagar budaya, tim ahli cagar budaya memerlukan bantuan dari juru pelihara di daerah untuk melaporkan setiap benda cagar budaya yang dipeliharanya.

Pemilihan dan penempatan juru pelihara merupakan bagian penting yang memiliki ikatan dalam peraturan pemerintah. Menurut UU No. 11 Tentang Cagar Budaya (2010: pasal 76 butir 5) Pemerintah dan Pemerintah Daerah dapat mengangkat atau menempatkan juru pelihara untuk melakukan perawatan Cagar Budaya. Artinya setiap juru pelihara dipilih oleh pemerintah dan diseleksi berdasarkan persyaratan menurut aturan yang berlaku. Kebijakan pengangkatan juru pelihara merupakan kewenangan dari tiap pemerintah daerah. Pemerintah daerah memiliki otonomi daerah dalam pengelolaan wilayahnya termasuk juga potensi yang ada dalam wilayah tersebut.

\section{Situs Cagar Budaya}

Dalam setiap kehidupan manusia tentuya memiliki sebuah jejak sejarah. Jejak sejarah merupakan bukti nyata dari kebudayaan manusia. Sisa-sisa kebudayaan manusia masa lalu tersebut oleh pakar arkeologi sering digunakan untuk merekontruksi kehidupan manusia masa lalu. Secara umum bekas-bekas kegiatan manusia masa lalu tersebut dapat dibagi dalam 4 kategori, yaitu : (1) artefak (artifact); (2) ekofak (ecofact); (3) fitur (feature); (4) situs (site) (Oka A Yoeti, 2006:317).

Setiap hasil dari sebuah kebudayaan seperti benda-benda tersebut akan menjadi sebuah cagar budaya. Menjadi cagar budaya dapat menjadi ikon sebuah daerah. Penetapan menjadi cagar budaya telah diatur dalam peraturan pemerintah. Berdasarkan UU No. 11 tahun 2010 Pasal 1 butir 1 bahwa

Cagar Budaya adalah warisan budaya bersifat kebendaan berupa Benda Cagar Budaya, Bangunan Cagar Budaya, Struktur Cagar Budaya, Situs Cagar Budaya, dan Kawasan Cagar Budaya di darat dan/atau di air yang perlu dilestarikan keberadaannya karena memiliki nilai penting bagi sejarah, ilmu pengetahuan, pendidikan, agama, dan/atau kebudayaan melalui proses penetapan.

Sebuah benda peninggalan sejarah tentunya akan menjadi sebuah benda budaya atau menjadi bagian dari cagar budaya. Benda-benda hasil kebudayaan ini disebut dengan benda cagar budaya. Masyarakat luas sering mengatakan benda cagar budaya sebagai situs sejarah. Menurut UU No. 5 tahun 1992 tentang benda cagar budaya oleh Soebijantoro dalam jurnal agastya.

Benda cagar budaya yaitu benda cagar budaya bergerak dan tidak bergerak. Secara khusus benda cagar budaya bergerak berupa kesatuan atau kelompok bagian - bagian atau sisanya yang berumur sekurang 
kurangnya 50 ( lima puluh) tahun atau mewakili masanya yang khas dan mewakili gaya sekurang - kurangnya 50 ( lima puluh) tahun serta dianggap mempunyai nilai penting bagi sejarah, ilmu pengetahuan dan kebudayaan. Sedangkan benda cagar budaya tidak bergerak berupa benda alam yang dianggap mempunyai nilai penting bagi sejarah, ilmu pengetahuan dan kebudayaan.

Dari penjelasan diatas benda cagar budaya merupakan kesatuan benda yang berumur lebih dari 50 tahun, baik benda bergerak maupun benda alam dan memiliki manfaat terhadap perkembangan sejarah, ilmu pengetahuan dan kebudayaan bagi masyarakat serta wilayahnya. Sehingga benda cagar ini mampu dimanfaatkan oleh pihak terkait untuk pembangunan dan kemajuan bangsa Negara.

Namun seiring perkembangan waktu terdapat beberapa perubahan dalam menjadi sebuah benda cagar budaya Terdapat beberapa amandemen dalam peraturan undang-undang tentang cagar budaya. Dalam UU No.11 Tahun 2010 Tentang Cagar Budaya Pasal 1 butir 2 menerangkan bahwa Benda Cagar Budaya adalah benda alam dan/atau benda buatan manusia, baik bergerak maupun tidak bergerak, berupa kesatuan atau kelompok, atau bagian-bagiannya, atau sisa-sisanya yang memiliki hubungan erat dengan kebudayaan dan sejarah perkembangan manusia. Artinya yakni benda cagar budaya merupakan bagian dari sejarah kebudayaan manusia yang berupa benda alam dan benda buatan manusia.

Benda cagar budaya merupakan bagian dalam wilayah cagar budaya. Lokasi yang terdapat benda cagar budaya merupakan bagian dari sebuah situs. Situs merupakan bidang tanah tempat dari kegiatan masyarakat masa lau. Di situs terdapat benda penginggalan yang dapat merupakan gabungan dari artefak, ekofak dan fitur (Oka A Yoeti, 2006:318). Karena adanya benda cagar budaya dalam sebuah situs maka tempat tersebut dijadikan sebagai situs cagar budaya. Situs cagar budaya adalah lokasi yang berada di darat dan/atau di air yang mengandung Benda Cagar Budaya, Bangunan Cagar Budaya, dan/atau Struktur Cagar Budaya sebagai hasil kegiatan manusia atau bukti kejadian pada masa lalu (UU No. 11 Tentang Cagar Budaya, 2010:Pasal 1).

Dalam hal ini sebuah situs cagar budaya merupakan lokasi yang dilindungi oleh peraturan pemerintah. Selain itu juga memiliki perlindungan dari pihak-pihak resmi pemerintah. Sebuah lokasi dijadikan sebagai situs cagar budaya karena memiliki bukti peristiwa sejarah dan hasil dari aktivitas manusia pada masa lalu. Buktibukti sejarah ini masih dirawat dengan baik sebagai bagian dari sejarah perkembangan wilayah. Dalam sebuah lokasi ada yang memiliki lebih dari dua situs cagar budaya. Lokasi yang demikian merupakan bagian dari kawasan cagar budaya. Perbedaan 
dengan situs cagar budaya adalah kawasan cagar budaya menjadi lokasi dari kumpulan situs cagar budaya.

\section{Metode Penelitian}

\section{A. Tempat Dan Waktu Penelitian}

Penelitian ini dilakukan di Madiun, Jawa Timur. Madiun memiliki 13 Situs Cagar Budaya yang akan menjadi tempat penelitian. Situs Cagar Budaya ini terdapat di Kabupaten Madiun dan Kota Madiun. Madiun merupakan daerah yang memiliki banyak benda cagar budaya. Benda cagar budaya di Madiun terdiri dari berbagai macam jenis, mulai dari struktur candi hingga bangunan masjid. Untuk itu Madiun menjadi tempat dilakukannya penelitian ini. Selain itu objek permasalahan merupakan juru pelihara benda cagar budaya yang berada di Madiun.

Penelitian ini dilakukan selama 6 bulan, yaitu mulai dari bulan Februari sampai bulan Juli 2014. Waktu penelitian ini dibuat karena terdapat 18 juru pelihara yang berada di wilayah Kabupaten Madiun dan Kota Madiun.

\section{B. Pendekatan dan Jenis Penelitian}

Penelitian ini menggunakan pendekatan kualitatif. Pendekatan kualitatif merupakan metode penelitian yang digunakan untuk meneliti pada kondisi obyek yang alamiah, dimana peneliti adalah sebagai instrumen utama, teknik pengumpulan data dilakukan secara triangulasi, analisis data bersifat induktif, dan hasil penelitian kualitatif menekankan pada makna (Sugiyono, 2013:15). Pada dasarnya penelitian kualitatif digunakan dalam penelitian yang merujuk pada obyek dan fenomena yang terjadi secara alami. Adapun data yang akan diperoleh akan bersifat deskriptif karena menggunakan pendekatan induktif.

Sedangkan jenis penelitian yang dilakukan yaitu jenis penelitian deskriptif. Metode deskriptif merupakan prosedur pemecahan masalah yang diselidiki dengan menggambarkan/melukiskan keadaan subyek/obyek penelitian pada saat sekarang berdasarkan fakta yang sebenarnya (Hadari Nawawi, 2005:63). Penelitian deskriptif terbatas pada usaha untuk mengungkap suatu masalah atau peristiwa sebagaimana adanya sehingga bersifat untuk mengungkap fakta.

Analisis data yang dilakukan dalam penelitian deskriptif tidak untuk menerima atau menolak hipotesis, melainkan berupa deskripsi atas gejala yang diamati yang tidak selalu berbentuk angka-angka atau koefisien antar variable (I Made Wiraartha, 2006:135). Gejala-gejala alamiah yang diteliti merupakan gejala yang secara natural terjadi pada objek penelitian seperti ucapan dan perilaku pada objek. Untuk itu dalam prosedur metode penelitian kualitatif menghasilkan data deskriptif berupa ucapan atau tulisan dan perilaku yang dapat diamati dari subyek (Arif Furchan, 1992:21-22). 


\section{Sumber Data}

Sumber data penelitian ini merupakan sumber data primer dan sumber data sekunder yang dapat menjelaskan informasi yang diperlukan dalam penelitian. Sumber data pada penulisan ini diperoleh dari:

\section{Sumber Data Primer}

Sumber data primer merupakan sumber data utama yang diperoleh secara langsung dari informan yang dapat dipercaya atas kebenaran dana mampu memberikan informasi yang dibutuhkan peneliti. Data primer adalah data yang diperoleh secara langsung dari masyarakat baik yang dilakukan melalui wawancara, observasi dan alat lainnya (Joko Subagjo, 2004:87). Menurut Husein Umar (2011:42) data primer merupakan data yang diperoleh dari sumber pertama baik dari individu atau perseorangan seperti hasil dari wawancara atau hasil pengisian kuisioner yang biasa dilakukan oleh peneliti.

\section{Sumber Data Sekunder}

Menurut Gabriel Amin (2003:57) yang dimaksud sumber data sekunder adalah data penelitian yang diperoleh dari peneliti secara tidak langsung melalui media perantara (diperoleh dan dicatat oleh pihak lain). Data sekunder umumnya berupa bukti, catatan, atau laporan historis yang telah tersususun dalam arsip yang tidak dipublikasikan.

\section{Teknik Analisa Data}

Analisis data merupakan proses mencari dan menyusun secara sistematis data yang diperoleh dari hasil wawancara, catatan lapangan, dan dokumentasi, dengan cara pengorganisasian data ke dalam kategori, menjabarkan ke dalam unit-unit, melakukan sintesa, menyusun dalam pola, memillih mana yang paling penting untuk dipelajari, dan membuat kesimpulan agar semua bisa faham (Sugiyono,2013:335).

Menurut Milles and Hubberman (1992:16) analisis data terdiri dari tiga alur kegiatan yang terjadi secara bersamaan yaitu: reduksi data, penyajian data, penarikan kesimpulan/verifikasi.

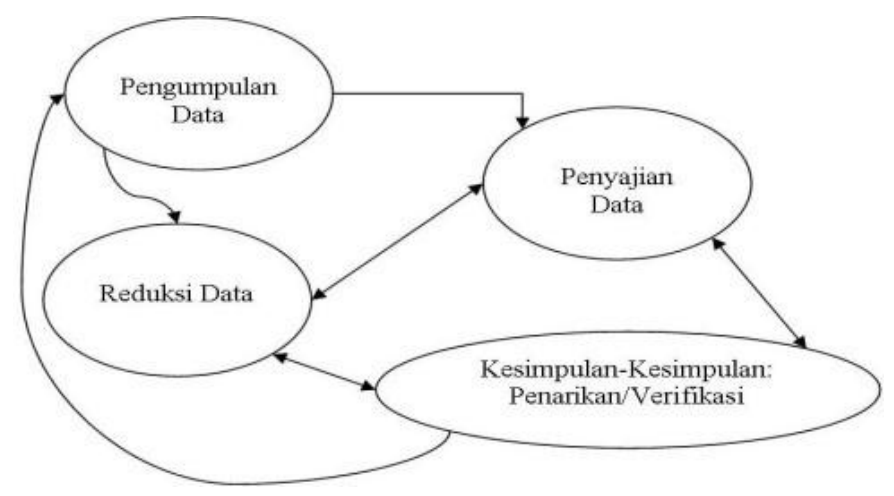

Bagan 3.2: Analisis data model interaktif (Miles \& Huberman, 1998:20).

\section{Hasil Penelitian}

Juru pelihara merupakan seseorang yang bertugas untuk merawat dan memelihara Benda Cagar Budaya. setiap kondisi dan kelestarian dari Benda Cagar Budaya menjadi tanggung Jawab dari juru pelihara. Kemudian juru pelihara bertanggung Jawab kepada pihak terkait yaitu kepada BPCB Trowulan dan kepada 
Provinsi. Untuk keberadaan juru pelihara sendiri dulunya merupakan seorang juru kunci dari situs yang mereka jaga. Banyak dari juru pelihara menjadi jupel karena turun-menurun dari keluarga mereka yang menjadi seorang juru kunci. Adapula juru pelihara yang memang dipilih oleh masyarakat setempat melalui pemilihan umum.

Selain itu ada yang menjadi juru pelihara karena memang ditugaskan dari BPCB atau dari Provinsi. Pengangkatan dan penetapan juru pelihara dilakukan melalui seleksi dan juga melalui pelatihan menjadi jupel. Kebanyakan juru pelihara diangkat dari warga sekitar di daerah Benda Cagar Budaya agar mempermudah koordinasi. Dalam pengangkatan juga dikeluarkan SK sebagai badan hukum dalam menjalankan tugas menjadi jupel. Sehingga tidak menimbulkan konflik dalam masyarakat.

Di Jawa Timur terdapat total 24 juru pelihara yang tersebar di dalam 262 Situs Cagar Budaya. Di wilayah Madiun terdapat 13 Situs Cagar Budaya yang terdiri dari 2 Situs Cagar Budaya di Kota Madiun dan 11 Situs Cagar Budaya di Kabupaten Madiun. keberadaan juru pelihara di Madiun sudah ada sekitar tahun 90'an sementara itu untuk juru kunci sudah ada sejak sebelum munculnya nama juru pelihara. namun kebanyakan juru peliharan mendapatkan SK pengankatan menjadi juru pelihara sekitar tahun 2000.
Adapun pengangkatan juru pelihara di Jawa Timur merupakan wewenang dari balai pelestarian dan juga dari Provinsi. Secara keseluruhan kedua instansi memberikan tunjangan. Namun dari pihak pemerintah daerah belum memberikan tunjangan kepada juru pelihara dan pemeliharaan Benda Cagar Budaya. hanya disaat tertentu mendapatkan bingkisan sebagai upaya untuk menghargai juru pelihara. sedangkan untuk pemberian jumlah tunjangan disesuaikan dengan status yang dimiliki oleh juru pelihara dan lingkup kelompok kerja juru pelihara.

Dalam kelompok satuan kerja di Jawa Timur terbagi menjadi 2 yaitu lingkungankerja balai pelestarian dan juga Provinsi. Secara keseluruhan status kepegawaian juru pelihara menjadi honorer dan PNS. Sementara status dari satuan kerja menjadi juru pelihara Trowulan, Juru pelihara Provinsi dan juru pelihara sukarela. Di Madiun terdapat 22 jupel dengan 6 jupel Trowula, 7 jupel Provinsi dan 9 jupel sukarela. Adapun untuk gaji dari Trowulan bagi jupel honorer sebesar 1 juta yang diberikan setiap bulan dan PNS disesuaikan oleh golongan. Untuk jupel Provinsi semuanya merupakan jupel honorer dengan gaji 300 ribu per bulan yang diberikan tiap 3 bulan sekali. Sedangkan untuk jupel sukarela belum mendaptkan tunjangan.

Tunjangan yang diberikan kepada juru pelihara belum mampu untuk memenuhi kehidupan seharai-harii dari juru 
pelihara. banyak dari juru pelihara memiliki profesi lain dari seorang juru pelihara. profesi ini dilakukan untuk menambah penghasilan guna memenuhi kebutuhan. Namun jupel tetap tidak meninggalkan tanggung Jawab sebagai juru pelihara. pkerjaan yang dilakukan antara lain sebagai pedagang, makelar, pegawai swasta, petani, buruh dan ada yang menjadi seniman.

Selain itu pemeliharaan Benda Cagar Budaya dan pemenuhan kebutuhan juru pelihara didapat dari hasil infaq maupun juga imbalan yang diberikan pengunjung secara sukarela. Dalam hal ini dari pihak yang menaungi jupel tidak melarang adanya infaq ini selama memang baik dan tetap adanya pengawasan dari pihak terkait. Adapun tanggapan masyarakat ada yang beranggapan baik bahwa jupel mampu membantu masyarakat dalam pelastarian Benda Cagar Budaya. namun ada yang dulunya berpikir aneh dan remeh terhadap keberadaan jupel sendiri.

\section{Pembahasan}

\section{A. Sejarah Keberadaan Juru Pelihara Cagar Budaya di Madiun}

Juru pelihara adalah seseorang yang bertugas untuk menjaga, melestarikan dan merawat situs atau Benda Cagar Budaya. Menurut Pasal 62 UU No. 11 Tahun 2010 Tentang Cagar Budaya bahwa Pengamanan Cagar Budaya untuk menjaga dan mencegah Cagar Budaya agar tidak hilang, rusak, hancur, atau musnah. Dapat dilakukan oleh juru pelihara dan/atau polisi khusus. Adapun jumlah juru pelihara di Jawa Timur sekitar 240 juru pelihara yang tersebar dari Madiun sampai banyuwangi. Untuk jumlah juru pelihara paling banyak berada di wilayah Mojokerto.

Sebagian besar juru pelihara merupakan seorang juru kunci. Adanya perubahan nama ini bertujuan untuk memperhalus bahasa dan penyebutan. Selain itu agar tidak menimbulkan pemahaman yang salah tentang juru pelihara. Yang merupakan seorang juru pelihara dipilih berdasarkan letak wilayah dengan Benda Cagar Budaya dan mengetahui serta memahami tentang Benda Cagar Budaya yang dilestarikan. Hal ini dimaksudkan agar letak dari Benda Cagar Budaya dan juru pelihara berdekatan. Sehingga mempermudah pemeliharan dan pengawasan terhadap Benda Cagar Budaya.

Untuk asal mula keberadaan juru pelihara berawal dari juru kunci yang menjaga tempat keramat. Dalam masa pemerintahan kerajaan di Jawa Terdapat lima tingkatan jabatan untuk mengurusi pemerintahan dalam kerajaan di Jawa antara lain : Pejabat-pejabat tinggi dalam kraton dan daerah Kutanagara, Pejabatpejabat di wilayah agung, Pejabat-pejabat di wilayah mancanegara, Pejabat-pejabat di daerah pasisiran dan jabatan-jabatan lebih rendah. Para abdi dalem ini ditempatkan sesuai dengan bidang keahliannya. Pada masa saat ini orang yang memiliki keahlian 
sering disebut dengan Juru. Misalkan orang yang bertugas mengelola tempat suci atau keramat disebut juru kunci (Moedjianto, 1997:113-116)

Oleh itu keberadaan juru pelihara yang bermula dari juru kunci menjadi bagian penting dalam usaha pelestarian Benda Cagar Budaya dan benda peninggalan nenek moyang karena antara juru kunci dan temapt peninggalan sejarah terdapat hubungan historis secara religi. Khusus di Madiun pada saaat ini total terdapat 22 juru pelihara 7 dari juru pelihara Provinsi dan 6 juru pelihara tergabung dalam Trowulan, jadi sisanya merupakan juru pelihara sukarela atau masih dalam usulan.

Untuk asal mula juru pelihara di Madiun belum bisa ditentukan secara pasti awal keberadaannya. Hal ini terjadi karena setiap juru pelihara di Madiun memiliki tahun yang berbeda dan latar belakang yang berbeda. Sebagai contohnya untuk juru pelihara taman menjadi juru pelihara sejak tahun 1987 yang kemudian dikeluarkannya SK menjadi jupel tahun 1999. Lain halnya dengan juru pelihara kelompok arca yang menjadi jupel sejak tahun 1986 dan dikeluarkan sk tahun 1998. Ada juga juru pelihara yang menjadi jupel pada tahun 2004 seperti jupel wonorejo dan tahun 2007 yaitu jupel situs mangirejo.

Selain itu berbeda dengan juru pelihara sukarela yang berada di Situs Makam Kuncen Mejayan. Jupel di Makam Kuncen Mejayan menjadi jupel dengan melalui pemilihan oleh warga desa. Jupel dipilih dengan berbagai criteria. Seseorang dianggap memiliki kemampuan untuk dipilih untuk menjadi jupel di makam kuncen mejayan. Namun untuk saat ini tradisi yang demikian sudah tidak dilakukan karena jupel sekarang sudah mulai untuk ditetapkan.

Sehingga secara khusus keberadaan juru pelihara di Madiun belum bisa ditentukan secara pasti. Namun untuk keberadaan juru pelihara di Madiun sebelumnnya sebagian besar berasl dari juru kunci. Adapun untuk pengangkatan menjadi jupel sesuai dengan SK jupel yang dikeluarkan dari Kementerian Pendidikan dan Kebudayaan juga dari Provinsi. Hal ini baik adanya karena dengan adanya SK pengangkatan jupel memiliki kekuatan hukum yang sah dalam menjalankan tugas. Tentunya ini juga mempermudah koordinasi dengan pihak pusat dan masyarakat dalam bidang kebudayaan.

Hal ini tentunya merupakan bagian penting dalam setiap pembahasan Benda Cagar Budaya. Karena munculnya juru pelihara adalah sebagai bagian dari Benda Cagar Budaya. Adanya interaksi antara Benda Cagar Budaya dengan masyarakat membutuhkan penyambung yaitu seorang jupel. Sehingga perlu adanya penentuan secara jelas sejarah keberadaan jupel yang digunakan sebagai acuan dalam sebuah pembelajaran. 


\section{B. Kehidupan Sosial Ekonomi Juru Pelihara Cagar Budaya di Madiun}

Untuk pengangkatan dan pemilihan jupel Benda Cagar Budaya kebanyakan dari masyarakat sekitar atau dulunya juga juru kunci. Sebenarnya untuk menjadi jupel harus melalui pelatihan dan menguasai pengetahuan tentang Benda Cagar Budaya. Pemilihan dan penempatan juru pelihara merupakan bagian penting yang memiliki ikatan dalam peraturan pemerintah. Pemerintah dan Pemerintah Daerah dapat mengangkat atau menempatkan juru pelihara untuk melakukan perawatan Cagar Budaya. Artinya setiap juru pelihara dipilih oleh pemerintah dan diseleksi berdasarkan persyaratan menurut aturan yang berlaku. Kebijakan pengangkatan juru pelihara merupakan kewenangan dari tiap Pemerintah Daerah (UU No. 11 Tentang Cagar Budaya , 2010: pasal 76 butir 5).

Dalam pengangkatan jupel wilayah merupakan wewenang dari pihak Pemerintah Daerah baik itu Provinsi maupun juga dari kabupaten. Dalam lingkup Provinsi tentunya jupel merupakan bagian dari tim ahli cagar budaya. Seperti dalam Keputusan Gubernur No. 50 tahun 2013 tentang Tim Ahli Cagar Budaya Jawa Timur telah diputuskan bahwa tim ahli cagar budaya berhak membentuk pembantu pelaksana sesuai dengan kebutuhan. Pembantu pelaksana dalam hal ini merupakan juru pelihara yang terletak di setiap daerah di Jawa Timur. Sehingga juru pelihara bertanggung Jawab tugas kepada Provinsi dan kepada BPCB Trowulan di Jawa Timur.

Oleh karena itu muncul kategori dalam setiap status juru pelihara. setiap juru pelihara memiliki status yang berbeda dengan juru pelihara lainnya. Ini muncul karena surat keterangan yang dimiliki oleh juru pelihara dikeluarkan bukan dari satu lembaga melainkan dari berbagai lembaga yang berbeda. Untuk tunjangan yang dikeluarkan juga muncul dari lembaga pemerintahan yang mengeluarkan surat tersebut. Adanya status yang berbeda diantara jupel ditakutkan akan menimbulkan kesenjangan sosial yang terjadi diantara jupel. Namun maslah ini untuk saat ini belum terjadi dan mungkin tidak akan terjadi. Karena dari pihak pemerintah telah berusaha melakukan penyetaraan dan pengawasan terhadp juru pelihara.

Untuk saat ini terdapat 3 macam kalsifikasi juru pelihara. Diantaranya yaitu juru pelihara dari BPCB Trowulan, Provinsi dan juru pelihara dari kabupaten. Dalam klasifikasi secara status dalam kepegawaian terbagi menadi 3 macam yaitu juru pelihara yang sudah menjadi PNS, juru pelihara honorer dan juru pelihara sukarela. Untuk juru pelihara yang berasal dari BPCB Trowulan surat pengangkatan dikeluarkan dari kementerian pendidikan dan kebudayaan. 
Sekarang ini di Madiun sendiri terdapat sekitar 22 juru pelihara yang berada di Kota dan Kabupaten Madiun. 22 orang juru pelihara ini diantaranya 6 orang merupakan juru pelihara yang ditetapkan dari BPCB Trowulan dan 7 orang merupakan juru pelihara dari Provinsi. Sementara itu lainnya merupakan juru pelihara dari kabupaten yang secara sukarela menjadi jupel. Dari jumlah yang demikian ada juru pelihara yang menjadi juru pelihara BPCB Trowulan dan juga juru pelihara Provinsi. Selain itu juga hanya ada satu juru pelihara yang sudah menjadi PNS yaitu juru pelihara cagar budaya taman.

Jumlah juru pelihara yang sudah terdaftar dalam lingkup BPCB Trowulan berjumlah 6 orang yang satu diantaranya sudah menjadi PNS. Untuk juru pelihara yang lain merupakan juru pelihara honorer. Berdasarkan SK jupel yang dikeluarkan oleh BPCB Trowulan sekarang ini tunjangan jupel honorer sekitar Rp. 1.000.000,- tiap bulan. Sementara untuk yang berstatus PNS disesuaikan dengan golongannya. Pada masa sebelumnya sekitar tahun '90an gaji jupel sekitar Rp. 75.000,- kemudian di tahun 2000an naik menjadi Rp.160.000,dan secara bertahap naik menjadi Rp. 300.000,- sampai sekarang sudah sekitar Rp. 1.000.000,- tiap bulan.

Sementara itu untuk juru pelihara dalam lingkup Provinsi di Madiun sendiri berjumlah 7 jupel. Kebanyakan jupel sebelum menjadi jupel di BPCB Trowulan terlebih dahulu telah menjadi jupel Provinsi. Jadi kebanyakan jupel BPCB Trowulan juga merupakan jupel Provinsi. Semua jupel Provinsi merupakan jupel honorer. Berdasarkan SK jupel tahun 2005 tunjangan yang diberikan dari Provinsi untuk jupel sekitar Rp.160.000,- yang kemudian naik menjadi Rp. 300.000,- tiap bulan dan diambil tiap 3 bulan sekali.

Kemudian untuk jupel sukarela tunjangan dari Pemerintah Daerah belum ada dan untuk pemeliharan Benda Cagar Budaya juga belum ada anggaran secara khusus. Namun masih ada bingkisan yang diberikan kepada jupel dari Kabupaten Madiun setiap hari besar. Belum adanya gaji dari Pemerintah Daerah dikarenakan belum adanya perda yang mengatur tentang jupel dan Benda Cagar Budaya. Tetapi pihak pemerintah tetap melindungi keberadaan jupel. Keterangan ini dibuktikan dengan adanya penilai kebudayaan di setiap kecamatan di Kabupaten Madiun. Selain itu pada tahun 2015 mulai diusulkan perda tentang anggaran untuk jupel dan Benda Cagar Budaya. Dengan demikian jupel untuk saat ini jupel akan terbantu melalui koordinasi dengan penilai budaya setempat dalam pemeliharaan Benda Cagar Budaya.

Dengan penghasilan menjadi jupel yang demikian, kebanyakan jupel belum mampu memenuhi kebutuhan ekonomi secara sepenuhnya. Untuk itu jupel memiliki profesi lain disamping menjadi jupel. Perbedaan status jupel tentunya 
mempengaruhi pemenuhan ekonomi dan juga kondisi sosial dari para juru pelihara. efeknya tentu mempengruhi sebuah inetraksi sosial diantara juru pelihara dan lingkungannya. Interaksi sosial merupakan hubungan sosial yang dinamis yang menyangkut hubungan antara perorangan dan kelompok sosial (Soerjono Soekanto, 1990:67). Sebuah interaksi jupel dengan masyarakat dilakukan denagn tujuan membangun peningkatan taraf hidup dan mengetahui status sosial mereka melaui tingkat pendidikan.

Interaksi yang dilakukan ini merupakan sebuah usaha yang dilakukan untuk memenuhi kebutuhan dari juru pelihara sendiri. Melalui komunikasi antara individu dan masyarakat ini memunculkan sikap untuk saling membutuhkan antara sesama sehingga nantinya akan muncul sebuah aktivitas ekonomi. Aktivitas ekonomi yang dilakukan oleh juru pelihara tentunya untk memenuhi kebutuhan mereka. Banyak dari juru pelihara yang bekerja sebagai buruh tani, penjual bunga dan makelar. Selain itu interaksi yang dilakukan bertujuan juga untuk memberdayaakan potensi masyarakat sekitar. Hal ini akan mampu meningkatkan ekonomi masyarakat sekitar. Misalkan saja jupel situs mangirejo yang mampu mendirikan Lembaga Swadaya Masyarakat dan tentunya mampu menjual hasil kerajinan dari pemuda sekitar.
Selain itu ada juga jupel yang menjadi seniman dhongkrek. Yang juga masih tetap melestarikan kebudayaan daerah setempat. Di samping itu ada jupel yang mendampingi peziarah dalam kegiatan ziarah di makam tokoh. Pekerjaan lain yang dimiliki jupel yaitu menjadi pedagang dan penjual bunga untuk minyak wangi. Namun beberapa jupel sukarela ada tambahan kebutuhan dari infaq, yang juga dikelola untuk pemeliharan Benda Cagar Budaya. Untuk itu perlu adanya peningkatan kesejahteraan untuk jupel dari pemerintah. Peningkatan ini perlu mengingat kondisi dari jupel yang memang belum sepenuhnya terjamin dalam pemenuhan sehari-hari dan juga jupel merupakan bagian dari rekan kerja dalam bidang kebudayaan.

\section{Penyelesaian Terhadap Masalah Sosial Ekonomi Juru Pelihara Benda Cagar Budaya di Madiun}

Permasalahan sosial ekonomi yang dihadapi juru pelihara merupakan permasalahan yang nyata. Tentunya ini memerlukan bantuan dari berbagai pihak yang terkait. Namun seiring berjalannya waktu juru pelihara sendiri sudah mampu mengurangi ataupun bahkan menyelesaikan permasalahan ekonomi yang ada pada mereka. Secara jelas para juru pelihara mampu berkembang dalam kondisi sosial yang demikian untuk memenuhi kebutuhan ekonomi. Tindakan-tindakan yang 
dilakukan juga memberikan pengaruh terhadap masyarakat sekitarnya.

Banyak dari para juru pelihara yang sudah memiliki profesi yang mampu memenuhi kebutuhan mereka. Namun juga masih banyak yang memang sulit untuk memenuhi kebutuhan hidupnya. Hal ini dikarenakan mungkin karena memang tingkat pendidikan dan tingkat usia yang tidak lagi produktif. Dalam pemeliharaan dan perawatan benda budaya mereka masih terus mengabdi karena memang mereka mencintai profesi mereka sebagai juru pelihara Benda Cagar Budaya.

Permasalahan lain yang muncul adanya perbedaan status juru pelihara. Peristiwa ini merupakan permasalahan yang tidak bisa dihindari. Dalam masalah ini tidak ada pihak bersalah. Semua pihak mengambil keputusan yang benar. Adanya status ini bertujuan untuk menghargai kerja keras dan pengabdian dari para juru pelihara. namun kekurangan yang terjadi akan menimbulkan kesan tidak adanya keadilan dalam professi jupel.

Tindakan yang saat ini telah dilakukan dari Pemerintah Daerah tentunya sudah mulai merencanakan anggaran khusus untuk pemeliharaan Benda Cagar Budaya dan tunjangan juru pelihara. selain itu juga setiap tahunnya Pemerintah Daerah selalu memperbarui usulan jupel dan usulan penambahan jupel kepada pihak terkait. Namun sampai saat ini masih belum ada keputusan di karenakan kuota atau jumlah tiap tahun dari pusat diperuntukkan bagi peningkatan kesejahteraan jupel yang sudah terdaftar. Sementara itu dari pihak Provinsi dan BPCB Trowulan selalu mengelola anggaran yang digunakan untuk mensejahterakan jupel yang ada dan tetap mengusulkan pada pihak Kementerian Pendidikan Dan Kebudayaan. Karena pihak KEMENDIKBUD yang berhak memutuskan dan mengeluarkan SK juru pelihara.

\section{Simpulan}

juru pelihara merupakan seseorang yang bertugas untuk menjaga, melestarikan dan merawat Situs atau Benda Cagar Budaya. Seorang juru pelihara dulunya merupakan juru kunci yang kemudian ditetapkan menjadi juru pelihara Benda Cagar Budaya. Mereka menjadi jupel bukan hanya memenuhi kebutuhan ekonomi namun karena pengabdian dan rasa cinta untuk melestarikan terhadap nilai kebudayaan lokal sebagai identitas bangsa. Dalam menjadi juru pelihara harus melalui pelatihan, memiliki kemampuan dan pengetahuan dalam bidang kebudayaan. Dalam pengangkatan juru pelihara memiliki syarat khusus dan melalui seleksi secara khusus. Kemudian setelah itu dikeluarkan SK juru pelihara sebagai surat rekomendasi yang memiliki keabsahan secara hukum. Surat ini menerangkan tentang juru pelihara dan penetapan juru pelihara dalam pemeliharaan Benda Cagar Budaya. 
Di Madiun terdapat 22 juru pelihara dengan 3 klasifikasi juru pelihara yaitu 7 juru pelihara dari Provinsi, 6 juru pelihara dari BPCB Trowulan dan lainnya merupakan juru pelihara sukarela. Selain itu juga status kepegawaian juru pelihara yaitu PNS dan honorer. Untuk juru pelihara di BPCB Trowulan dengan status honorer gaji yang diterima sebesar Rp. 1.000.000,- tiap bulan. Sementara untuk PNS disesuaikan dengan golongannya. Sementara itu dari Provinsi sebesar Rp. 300.000,- tiap bulan dan diambil setiap 3 bulan sekali. Juru pelihara sukarela masih belum mendapat tunjangan dari Pemerintah Daerah. Namun tetap mendapat bingkisan disetiap hari besar dan pertemuan. Seberapa besar tunjangan juru pelihara yang diperoleh belum mampu mencukup kebutuhan ekonomi. Oleh karena itu juru pelihara memiliki pekerjaan lain disamping menjadi juru pelihara. Diantaranya menjadi pegawai swasta/karyawan, makelar, petani, pedagang, dan ada yang menjadi seniman.

Di samping mereka memiliki pekerjaan lain, mereka tetap tidak meninggalkan tugas mereka sebagai juru pelihara. Selain itu ada juru pelihara yang memang mampu memberdayakan masyarakat sekitar untuk meningkatkan perekonomian daerahnya dan potensi wilayahnya. Tentunya ini menjadi sebuah peran sosial yang baik dalam pengelolaan potensi daerah. Sehingga dapat disimpulkan secara jelas bahwa pada saat ini kehidupan sosial dan ekonomi yang dialami oleh juru pelihara telah mengalami perkembangan namun masih perlu sebuah perhatian kembali. Hal ini perlu guna meningkatkan kualitas hidup yang baik.

\section{Saran}

\section{Juru Pelihara Benda Cagar Budaya}

Sebagai salah satu bagian penting dalam pelestarian Benda Cagar Budaya di indonesia, hendaknya setiap juru pelihara tetap mempertahankan pengabdian yang dilakukan. Selain itu setiap juru pelihara memiliki pengetahuan dan kemampuan yang baik terhadap pemeliharaan Benda Cagar Budaya dan sistem birokrasi nasional. Juga diharapkan mampu mengelola potensi daerah khususnya dalam bidang sosial, budaya dan ekonomi untuk peningkatan perekonomian daerahnya.

\section{Pemerintah Kota dan Kabupaten Madiun}

Peneliti memiliki harapan yang besar kepada Pemerintah Daerah untuk mampu mengelola potensi daerah dalam bidang kebudayaan. Tentunya ini akan mampu meningkatkan pendapatan daerah dan kesejahteraan daerah. Harapan yang nyata juga peneliti sampaikan agar terwujudnya anggaran khusus terhadap pemeliharaan Benda Cagar Budaya dan kesejahteraan para juru pelihara setempat pada tahun selanjutnya.

\section{Pemerintah Provinsi Jawa Timur dan BPCB Trowulan}


Peneliti menaruh harapan besar kepada pihak Provinsi dan BPCB Towulan untuk selalu melakukan pendidikan kebudayaan guna meningkatkan wawasan dan kemampuan bidang kebudayaan. Selain itu juga diharapkan mampu memberikan kesejahteraan yang lebih baik kepada para juru pelihara dan pemeliharaan yang lebih baik lagi pada Benda Cagar Budaya.

\section{Daftar Pustaka}

Abu Ahmadi. 1991. Sosiologi Pendidikan. Jakarta: Rineka Cipta

Arif Furchan. 1992. Pengantar Metoda Penelitian Kualitatif Suatu Pendekatan Fenomenologis terhadap Ilmu-Imu Sosial. Surabaya: Usaha Nssional

Basrowi Dan Suwandi. 2008. Memahami Penelitian Kualitatif. Jakarta: Rineka Cipta

Burhan Bungin. 2007. Penelitian Kualitatif KOmunikasi, Ekonomi, Kebijakan Publik Dan Ilmu Sosial Lainnya. Jakarta: Kencana

Dadang Supardan. 2008. Pengantar Ilmu Sosial. Jakarta: Bumi Aksara

Damsar. 2009. Pengantar Sosiologi Ekonomi. Jakarta: Prenada Media Group

Dany Haryanto dan Edwin. 2011. Pengantar Sosiologi Dasar. Jakarta: Prestasi Pustaka

Gabriel Amin Silalahi. 2003. Metode Penelitian Dan Studi Kasus. Sidoarjo: CV Citra Media
Hadari Nawawi. 2005. Metode Penelitian Bidang Sosial. Yogyakarta: Gajahmada University Pres

H.B Sutopo. 2006. Metodologi Penelitian Kualitatif. Surakarta: Universitas Sebelas Maret

Husaini Usman Dan Purnomo Setiadi Akbar. 2004. Metode Penelitian Sosial. Jakarta: PT Bumi Aksara

Husein Umar. 2011. Metode Penelitian Untuk Skripsi Dan Tesis Bisnis. Jakarta RaJawali Pers

I Made Wiraartha. 2006. Metodologi Penelitian Sosiologi. Yogyakarta: Andi Yogyakarta

John Sabari. 2011. Agastya: Jurnal Sejarah Dan Pembelajarannya. Madiun: IKIP PGRI MADIUN

Joko Subagyo. 2004. Metode Penelitian dalam Teori Dan Praktek. Jakarta: PT Adhi Mahasatya

Miles, Mathew B dan A Michael Hubbermain. 1992. Analisis Data Kualitatif: Buku Sumber Tentang Metode-Metode Baru. Jakarta: UI Press.

Moedjianto. 1987. Konsep Kekuasaan Jawa Penerapannya Oleh Raja - Raja Mataram. Yogyakarta : kanisius

Oka A Yoeti. Dkk. 2006. Pariwisata Budaya Masalah Dan Solusinya. Jakarta: Malta Pritindo

Resty Nikiuluw. Desak Putu E. Made Susilawati. 2011. Agastya Jurnal Sejarah Dan Pembelajarannya. Madiun: Pendidikan Sejarah IKIP PGRI MADIUN

Ririn Darini. 2013. Sejarah Kebudayaan Indonesia Masa Hindu Buddha. Yogyakarta: Ombak 
Soebijantoro. 2013. Jurnal Agastya Pendidikan Sejarah. Madiun: Program Studi Pendidikan Sejarah IKIP PGRI Madiun

Soerjono Soekanto. 1990. Sosiologi Suatu Pengantar. Jakarta: Rajagrafindo Persada

Sugiyono. 2013. Metode Penelitian Pendidikan. Bandung: Alfabetha

Supardan, dadang. 2008. Penalaran Ilmu Sosial Sebuah Kajian Pendekatan Struktural. Jakarta: Bumi Aksara

Supardi. 2011. Dasar - Dasar Ilmu Sosial. Yogyakarta : Ombak

Undang-Undang Republik Indonesia. 2010. Undang-Undang Republik Indonesia Nomor 11 Tahun 2010 Tentang Cagar Budaya. Mojokerto: Balai Pelestarian Peninggalan Purbakala Trowulan

Keputusan Gubernur Nomor 50 Tahun 2013 Tentang Tim Ahli Cagar Budaya Provisi Jawa Timu 